\title{
Modulation of Fibroblast Growth Factor-2 Receptor Binding, Dimerization, Signaling, and Angiogenic Activity by a Synthetic Heparin-mimicking Polyanionic Compound
}

\author{
Hua-Quan Miao, ${ }^{\star}$ David M. Ornitz, ${ }^{\ddagger}$ Elena Aingorn, ${ }^{*}$ Shmuel A. Ben-Sasson,,$\$$ and Israel Vlodavsky* \\ *Department of Oncology, Hadassah-Hebrew University Hospital, Jerusalem 91120, Israel; $\doteqdot$ Department of Molecular Biology and \\ Pharmacology, Washington University Medical School, St. Louis, MO 63110; and ${ }^{\S}$ Department of Experimental Medicine, The Hebrew \\ University-Hadassah Medical School, Jerusalem 91120, Israel
}

\begin{abstract}
Heparan sulfate (HS) proteoglycans play a key role in cell proliferation induced by basic fibroblast growth factor (FGF-2) and other heparin-binding growth factors. To modulate the involvement of HS, we have used a synthetic, nonsulfated polyanionic aromatic compound (RG-13577) that mimics functional features of heparin/HS. FGF-2-stimulated proliferation of vascular endothelial cells was markedly inhibited in the presence of 5-10 $\mu \mathrm{g} / \mathrm{ml}$ compound RG-13577 (poly-4-hydroxyphenoxy acetic acid; Mr $\sim 5 \mathrm{kD}$ ). Direct interaction between RG-13577 and FGF-2 was demonstrated by the ability of the former to compete with heparin on binding to FGF-2. RG-13577 inhibited FGF-2 binding to soluble- and cell surface-FGF receptor 1 (FGFR1). Unlike heparin, RG-13577 alone failed to mediate dimerization of FGF-2. Moreover, it abrogated heparin-mediated dimerization of FGF-2 and FGFR1, as well as FGF-2 mitogenic activity in HS-deficient F32 lymphoid cells. The antiproliferative effect of compound RG-13577 was associated with abrogation of FGF-2-induced tyrosine phosphorylation of FGFR1 and of cytoplasmic proteins involved in FGF-2 signal transduction, such as p90 and mitogen-activated protein kinase. A more effective inhibition of tyrosine phosphorylation was obtained after removal of the cell surface HS by heparinase. In contrast, tyrosine phosphorylation of an $\sim 200-\mathrm{kD}$ protein was stimulated by RG-13577, but not by heparin or FGF-2. RG-13577 prevented microvessel outgrowth from rat aortic rings embedded in a collagen gel. Development of nontoxic polyanionic compounds may provide an effective strategy to inhibit FGF-2-induced cell proliferation associated with angiogenesis, arteriosclerosis, and restenosis. (J. Clin. Invest. 1997. 99:1565-1575.) Key words: angiogenesis - vascular endothelial cells - antiproliferative activity $\bullet$ heparan sulfate $\bullet$ heparin mimetics
\end{abstract}

Address correspondence to Israel Vlodavsky, Department of Oncology, Hadassah Hospital, P.O. Box 12000, Jerusalem 91120, Israel. Phone: 972.2.6776776; FAX: 972.2.6422794; E-mail: vlodavsk@cc.huji.ac.il

Received for publication 27 September 1996 and accepted in revised form 23 January 1997.

J. Clin. Invest.

(C) The American Society for Clinical Investigation, Inc.

0021-9738/97/04/1565/11 \$2.00

Volume 99, Number 7, April 1997, 1565-1575

\section{Introduction}

Fibroblast growth factors (FGFs) ${ }^{1}$ constitute a large family of monomeric growth factors involved in the control of cell growth, survival, and differentiation in processes such as embryogenesis, tissue repair, neovascularization, and nerve regeneration (1). Two classes of receptors for FGFs have been identified. One is a family of four tyrosine kinase receptors that bind FGFs with high affinity and transmit the biological response to the growth factor (2). The second class of receptors is the polysaccharide component of heparan sulfate (HS) proteoglycans found on cell surfaces and extracellular matrix (3-5). Heparin and cell surface heparinlike molecules bind FGF with low affinity but high capacity and do not transmit a biological response. Binding of FGF to heparin or HS was proposed to stabilize and protect the FGF molecule against inactivation (6) and/or to facilitate FGF receptor (FGFR) binding and oligomerization, resulting in transmembrane signaling and biological responses (5). It has also been reported that heparin binds to the FGF signaling receptor itself (7). Compounds that modulate the above proposed functions of heparin/HS are of increasing importance for the development of therapeutic agents of widespread utility (3). Among such compounds are suramin (8-10), pentosan polysulfate (11), laminarin sulfate (12), sucrose octasulfate $(13,14)$, and aurin tricarboxylic acid (ATA) (15). Of particular significance is the potential inhibition of angiogenesis induced by heparin-binding growth factors, and involved in the progression of cancer and of diseases caused by abnormal neovascularization (16).

In an attempt to identify potent mimetics of heparin/HS, acid-catalyzed polymerization of phenols and formaldehyde was used to synthesize negatively charged, nonsulfated polyanionic compounds (17). Aromatic ring monomers were chosen and strong oxidizing reagents avoided so that the polymerization process with formaldehyde would yield substantially ordered and defined backbones (17). Using this approach, a series of polyanionic polymers was identified with repeating phenol-based monomers, including poly-4-hydroxyphenoxy acetic acid, hereby termed compound RG-13577, that mimics various effects of heparin. Some of these nontoxic, nonsulfated linear polyanionic compounds were found to revert the transformed phenotype of FGF-2-transfected cells (18) and inhibit

1. Abbreviations used in this paper: ATA, aurin tricarboxylic acid; BAEC, bovine aortic endothelial cell; $\mathrm{CHO}$, Chinese hamster ovary; DSS, disuccinyimidyl suberate; FGF, fibroblast growth factor; FGF-1, acidic FGF; FGF-2, basic FGF; FGFR, FGF receptor; FRAP, FGFR1 ectodomain-alkaline phosphatase fusion protein; HS, heparan sulfate; MAPK, mitogen-activated protein kinase. 
the proliferation of vascular smooth muscle cells induced by thrombin, FGF-2, and serum (19).

The present study was undertaken to investigate and better elucidate the mode of action of compound RG-13577. For this purpose, we analyzed the effect of RG-13577 on FGF-2 receptor binding, dimerization, and phosphorylation, as well as on FGF-2-mediated cell proliferation and microvessel formation.

\section{Methods}

Materials. Recombinant human FGF-2 was kindly provided by Takeda Chemical Industries (Osaka, Japan) and by Scios Nova Inc. (Mountain View, CA). Bacterial Flavobacterium heparinase I (EC 4.2.2.7), II, and III were kindly provided by IBEX Technologies (Montreal, Canada). Sepharose 6B was from Pharmacia Fine Chemicals (Uppsala, Sweden). Tissue culture media (Dulbecco's modified Eagle's medium, F12, RPMI-1640, Serum-free Endothelial Growth Medium), fetal calf serum, and calf serum were obtained from Gibco Laboratories (Grand Island, NY). ${ }^{3} \mathrm{H}$-thymidine and $\mathrm{Na}^{125} \mathrm{I}$ were obtained from Amersham International (Little Chalfont, UK). Disuccinyimidyl suberate (DSS) was purchased from Pierce (Rockford, IL). All other chemicals were of reagent grade, purchased from Sigma Chemical Co. (St. Louis, MO). RG-13577 was prepared and kindly provided by Dr. J. Regan and Dr. M. Chang (Rhone-Poulenc Rorer Co., Collegeville, PA).

Cells. Bovine aortic endothelial cells (BAECs) were cloned and cultured in DMEM ( $1 \mathrm{~g}$ glucose/liter) supplemented with $10 \%$ calf serum $(20,21)$. Balb/c 3T3 fibroblasts were cultured in DMEM (4.5 g glucose/liter) as described (21). Glycosaminoglycan-deficient Chinese hamster ovary (CHO-pgsA-745) cells (22) were kindly provided by Dr. J.D. Esko (Department of Biochemistry, University of Alabama at Birmingham, Birmingham, AL). CHO-pgs A-745 cells were transfected with the cDNA for the murine two Ig-like ectodomain form of FGF-2 receptor-1 (flg), yielding CHO-pgsA-745-flg cells $(23,24)$. Cells were maintained in F-12 medium supplemented with $10 \%$ FCS. Clone $\mathrm{F} 32$ of $\mathrm{BaF}_{3}$ cells was grown in RPMI 1640 medium supplemented with $10 \%$ newborn calf serum, $10 \%$ interleukin-3-containing medium conditioned by X63-IL3 WHEI cells. F32 cells were obtained after transfection of $\mathrm{BaF}_{3}$ cells with $\mathrm{Mo} / \mathrm{mFRl} / \mathrm{SV}$ expression vector and selection in medium containing FGF-2 plus heparin, as described (25).

Binding assays. Heparin was iodinated using ${ }^{125} \mathrm{I}$-fluoresceinamine, as described (26). FGF-2 was iodinated using chloramine T, as described (24). Heparin binding to FGF-2 was determined by incubation of FGF-2 $(4 \mathrm{nM} ; 72 \mathrm{ng} / \mathrm{ml})$ with ${ }^{125} \mathrm{I}$-heparin in the absence or presence of RG-13577. Complexes were immunoprecipitated $(2 \mathrm{~h}$, $4^{\circ} \mathrm{C}$ ) with 1:250 dilution of an anti-FGF-2 monoclonal antibody (DG2; Dupont-Merck Pharmaceutical Co., Wilmington, DE) and protein A-Sepharose (1:4) (27). Bound ${ }^{125}$ I-heparin was recovered by centrifuging for $10 \mathrm{~s}\left(2,000 \mathrm{~g}, 4^{\circ} \mathrm{C}\right)$ and washing with PBS. ${ }^{125} \mathrm{I}$-heparin binding was determined by counting tubes directly in a gamma counter.

A soluble FGFR1 ectodomain-alkaline phosphatase (FRAP) fusion protein was constructed as described $(25,28)$. The components of the soluble receptor binding reaction mixture included FRAP-conditioned medium (300 U alkaline phosphatase (AP) activity) (28), ${ }^{125} \mathrm{I}-\mathrm{FGF}-2(1 \mathrm{ng} / \mathrm{ml})$, heparin, and/or RG-13577. The bound complex was immunoprecipitated with $20 \mu \mathrm{l}$ of a $2 \times$ slurry of anti-AP monoclonal antibodies coupled to Sepharose $\left(2 \mathrm{~h}, 4^{\circ} \mathrm{C}\right)(25,28)$. The total volume was brought to $250 \mu \mathrm{l}$ with binding medium (DMEM, $0.1 \%$ BSA, $25 \mathrm{mM}$ Hepes, $\mathrm{pH}$ 7.4) and the bound ligand was recovered by centrifuging for $10 \mathrm{~s}\left(2,000 \mathrm{~g}, 4^{\circ} \mathrm{C}\right)$ and washing two times with PBS. ${ }^{125}$ I-FGF-2 binding was determined by counting tubes directly in a gamma counter (25).

Confluent CHO-pgsA-745-flg cells, cultured in 24-well plates, were washed twice with binding medium and incubated with ${ }^{125} \mathrm{I}$ FGF-2 $\left(1 \mathrm{ng} / \mathrm{ml}, 2 \mathrm{~h}, 4^{\circ} \mathrm{C}\right)$ in the absence and presence of RG-13577 or heparin. ${ }^{125}$ I-FGF-2 binding to low and high affinity receptor sites on the cell surface was determined as described $(24,29,30)$.
Cross-linking. FGF-2 cross-linking was carried out as described $(14,25)$. Briefly, ${ }^{125} \mathrm{I}-\mathrm{FGF}-2(20 \mathrm{ng} / \mathrm{ml})$ was incubated $\left(1 \mathrm{~h}, 24^{\circ} \mathrm{C}\right)$ in the absence and presence of heparin $(0.5 \mu \mathrm{g} / \mathrm{ml})$ and/or various concentrations of RG-13577 in $20 \mu \mathrm{l}$ buffer containing $150 \mathrm{mM} \mathrm{NaCl}$ and $25 \mathrm{mM}$ Hepes, $\mathrm{pH}$ 7.5. DSS was then added to a final concentration of $0.15 \mathrm{mM}$ and the mixture was incubated for an additional $20 \mathrm{~min}$. The cross-linking reaction was quenched with $10 \mathrm{mM}$ ethanolamine- $\mathrm{HCl}$, $\mathrm{pH}$ 8.0, for $20 \mathrm{~min}$, and diluted 1:1 with $2 \times$ SDS-PAGE loading buffer. The soluble material was analyzed by $15 \%$ SDS-PAGE and the cross-linked FGF-2 was visualized by autoradiography on XAR film (Eastman Kodak Co., Rochester, NY).

${ }^{125}$ I-FGF-2 cross-linking to cell-surface receptors was performed in 10-cm culture dishes. CHO-pgsA-745-flg cells were incubated $(2 \mathrm{~h}$, $4^{\circ} \mathrm{C}$ ) with $1 \mathrm{ng} / \mathrm{ml}^{125} \mathrm{I}-\mathrm{FGF}-2$ in the absence or presence of $0.5 \mu \mathrm{g} / \mathrm{ml}$ heparin and increasing concentrations of RG-13577. The binding medium was removed, the cells were washed once with PBS containing $10 \mu \mathrm{g} / \mathrm{ml}$ heparin and $0.1 \%$ BSA, and once with PBS alone. The labeled cells were then incubated $\left(15 \mathrm{~min}, 24^{\circ} \mathrm{C}\right)$ with $0.3 \mathrm{mM}$ DSS and the reaction was quenched $\left(5 \mathrm{~min}, 24^{\circ} \mathrm{C}\right)$ by $10 \mathrm{mM}$ Tris- $\mathrm{HCl}, \mathrm{pH} 7.5$, $150 \mathrm{mM}$ glycine, and $2 \mathrm{mM}$ EDTA. The cells were washed with PBS and scraped into $1 \mathrm{ml}$ lysis buffer $(50 \mathrm{mM}$ Tris- $\mathrm{HCl}, \mathrm{pH}$ 8.0, $150 \mathrm{mM}$ $\mathrm{NaCl}, 1 \%$ Triton $\mathrm{X}-100,1 \% \mathrm{Na}$ deoxycholate, $1 \mathrm{mM}$ EDTA, $1 \mathrm{mM}$ EGTA, $1 \mathrm{mM}$ PMSF, $10 \mu \mathrm{g} / \mathrm{ml}$ leupeptin, and $10 \mu \mathrm{g} / \mathrm{ml}$ aprotinin) and incubated for $10 \mathrm{~min}$ on ice. The cell lysates were cleared by centrifugation $\left(12,000 \mathrm{~g}, 15 \mathrm{~min}, 4^{\circ} \mathrm{C}\right)$, boiled for $5 \mathrm{~min}$ in SDS-PAGE sample buffer, loaded onto a $7.5 \%$ polyacrylamide gel and visualized by autoradiography.

Tyrosine phosphorylation. Balb/c 3T3 cells were sparsely seeded on gelatin-coated 10-cm dishes. Subconfluent cultures were starved in DMEM (4.5 g glucose/liter) containing $0.5 \%$ FCS for $48 \mathrm{~h} .10 \mathrm{~min}$ before adding FGF-2 $(1 \mathrm{ng} / \mathrm{ml})$, various concentrations of RG-13577 were added and the cells were incubated for $10 \mathrm{~min}$ at $37^{\circ} \mathrm{C}$, rinsed once with $1 \mathrm{mM} \mathrm{Na}_{3} \mathrm{VO}_{4}$ in cold PBS, and lysed with lysis buffer (10 $\mathrm{mM}$ Tris, $\mathrm{pH} 7.4,1 \%$ Triton $\mathrm{X}-100,50 \mathrm{mM} \mathrm{NaCl}, 0.1 \mathrm{mM} \mathrm{Na}_{3} \mathrm{VO}_{4}, 30$ $\mathrm{mM} \mathrm{Na}{ }_{4} \mathrm{P}_{2} \mathrm{O}_{7}, 50 \mathrm{mM} \mathrm{NaF}, 5 \mathrm{mM}$ EDTA, $1 \mathrm{mM}$ PMSF). The lysates were cleared by centrifugation $\left(12,000 \mathrm{~g}, 20 \mathrm{~min}, 4^{\circ} \mathrm{C}\right)$ and $50 \mu \mathrm{g}$ total cell protein was subjected to $7.5 \%$ SDS-PAGE and blotted onto Immobilon $^{\mathrm{TM}}{ }_{-\mathrm{P}}$ membrane (Millipore Corp., Bedford, MA). The immunoblots were blocked by incubation $\left(37^{\circ} \mathrm{C}, 30 \mathrm{~min}\right)$ in $3 \% \mathrm{BSA}$ in TBST (20 mM Tris-HCl, pH 7.4, $150 \mathrm{mM} \mathrm{NaCl}, 0.5 \%$ Tween-20), followed by incubation $\left(16 \mathrm{~h}, 4^{\circ} \mathrm{C}\right)$ with primary antibodies; i.e., monoclonal antibodies $(1: 1,000)$ against phosphorylated tyrosine (PY-20; Transduction Laboratories, Lexington, KY); rabbit polyclonal antibodies against mitogen-activated protein kinase (MAPK) $(1: 5,000$, Sigma Israel, Rehovot, Israel), or rabbit anti-80K-H 804 polyclonal antibodies (1:2,000, a generous gift from Dr. K.C. Goh, Institute of Molecular and Cell Biology, National University of Singapore) (31). The membrane was washed $(8 \times)$ in TBST, followed by incubation (45 $\mathrm{min}, 24^{\circ} \mathrm{C}$ ) with horseradish peroxidase-conjugated sheep antimouse $\operatorname{IgG}(1: 3,000$, Amersham International), or goat anti-rabbit IgG (1:5,000, Sigma Israel). The immunoreactive proteins were detected by enhanced chemiluminescence detection system (ECL; Amersham International). To reprobe immunoblots with a different anti-serum, membranes were stripped by incubation $\left(30 \mathrm{~min}, 50^{\circ} \mathrm{C}\right)$ with $62.5 \mathrm{mM}$ Tris- $\mathrm{HCl}, \mathrm{pH} 6.7,2 \% \mathrm{SDS}$, and $100 \mathrm{mM}$ 2-mercaptoethanol, followed by incubation with antisera and processing as described above.

To study FGFR1 phosphorylation, $200 \mu \mathrm{g}$ of cell lysates were incubated with a rabbit polyclonal antibody against FGFR1 cytoplasmic domain (1:100, a generous gift from Dr. D. Ron, Department of Biology, Technion, Haifa, Israel). The complex was immunoprecipitated $\left(16 \mathrm{~h}, 4^{\circ} \mathrm{C}\right)$ with $50 \mu \mathrm{l}$ slurry of protein A-Sepharose, and the bound material was washed $(4 \times)$ with lysis buffer and dissolved in 30 $\mu \mathrm{l}$ of $2 \times$ SDS-PAGE loading buffer. The samples were subjected to $7.5 \%$ SDS-PAGE and immunoblotted with PY-20, as described above. In some experiments, ${ }^{125} \mathrm{I}-\mathrm{FGF}-2(1 \mathrm{ng} / \mathrm{ml})$, instead of unlabeled FGF-2, was applied to study FGFR tyrosine phosphorylation (32). For this purpose, Balb/c 3T3 cells were stimulated (10 min, 
$\left.37^{\circ} \mathrm{C}\right)$ with ${ }^{125} \mathrm{I}-\mathrm{FGF}-2(1 \mathrm{ng} / \mathrm{ml})$, followed by cross-linking (10 min, $\left.37^{\circ} \mathrm{C}\right)$ with $0.3 \mathrm{mM}$ DSS. Cell lysates $(500 \mu \mathrm{g})$ were incubated with PY-20 $(5 \mu \mathrm{g})$ and immunoprecipitated with protein A-Sepharose, and the phosphorylated FGFR was analyzed by $7.5 \%$ SDS-PAGE and autoradiography.

Cell proliferation. F32 cells were washed twice with RPMI 1640 medium. Cells $\left(2 \times 10^{4} /\right.$ well $)$ were plated in 96-well microtiter plates in the presence of $3 \mathrm{ng} / \mathrm{ml} \mathrm{FGF-2} \mathrm{and} \mathrm{increasing} \mathrm{concentrations} \mathrm{of}$ RG-13577, with or without heparin, in a total volume of $250 \mu \mathrm{l} .48 \mathrm{~h}$ later, $1 \mu \mathrm{Ci}$ of ${ }^{3} \mathrm{H}$-thymidine was added per well, the cells were incubated for an additional $6 \mathrm{~h}$ and collected with a PHD cell harvester (Cambridge Technology Inc., Watertown, MA). Incorporated thymidine was determined by liquid scintillation counting $(12,25)$.

For measurements of BAEC proliferation, cells were seeded at a low density $\left(10^{3} / 16-\mathrm{mm}\right.$ well) in $0.5 \mathrm{ml}$ DMEM containing $10 \%$ heatinactivated calf serum. $1 \mathrm{~d}$ after seeding, the medium was replaced by fresh medium containing various concentrations of RG-13577, and $3 \mathrm{~d}$ later the cells were exposed $\left(3 \mathrm{~h}, 37^{\circ} \mathrm{C}\right)$ to ${ }^{3} \mathrm{H}$-thymidine $(5 \mu \mathrm{Ci} /$ well $)$. DNA synthesis was determined by measuring the radioactivity incorporated into TCA-insoluble material $(33,34)$. Thymidine incorporation was linearly correlated to the number of cells per well. In other experiments, the BAECs were seeded at a clonal cell density (300 cells/35-mm dish) and cell colonies were fixed and stained with $0.1 \%$ crystal violet, $8-10 \mathrm{~d}$ after seeding $(20,21) .{ }^{3} \mathrm{H}$-Thymidine incorporation into growth-arrested Balb/c $3 \mathrm{~T} 3$ cells was performed as described $(21,34)$.

In vitro angiogenesis. Type I collagen was prepared from the tail tendons of adult Sprague-Dawley rats (35). The collagen matrix gel was obtained by simultaneously raising the $\mathrm{pH}$ and ionic strength of the collagen solution (36). Thoracic aortas were obtained from 2-mo-old Sprague-Dawley rats. The fibroadipose tissue was carefully removed under a dissecting microscope, and aortic rings were sectioned (1-mm long) (37) and placed on top of a 0.2-ml collagen gel in $16-\mathrm{mm}$ culture wells. Collagen solution $(0.4 \mathrm{ml})$ was carefully poured on top of the ring. After the gel was formed, $0.4 \mathrm{ml}$ serum-free endothelial growth medium was added and replaced every other day by fresh medium containing the indicated concentrations of RG-13577. Microvessel outgrowth was visualized by phase microscopy and the number of capillary vessels was counted throughout the course of the experiment. Upon completion of the experiment, samples were fixed with $4 \%$ formaldehyde, embedded in paraffin, and sectioned at $5 \mu \mathrm{m}$. Microvessel structures were confirmed by hematoxylin-eosin staining and immunostaining for von Willebrand factor.

\section{Results}

Effect of RG-13577 on FGF-2 binding to heparin/HS and FGFR1. FGF-2 binds avidly to heparin and HS $\left(K_{\mathrm{d}}=2 \times\right.$ $\left.10^{-9} \mathrm{M}\right)(29,38)$. We assayed the ability of the compound RG13577 to compete with the binding of ${ }^{125}$ I-labeled heparin to FGF-2. Heparin binding to FGF-2 was determined by incubation of FGF-2 with ${ }^{125}$ I-heparin in the absence and presence of increasing concentrations of unlabeled heparin or RG-13577. Complexes were immunopre33cipitated with anti-FGF-2 antibody (DG2) and protein A-Sepharose (27). RG-13577 failed to inhibit the binding of heparin to FGF-2 at concentrations $<1 \mu \mathrm{g} /$ ml. $50 \%$ competition for ${ }^{125}$ I-labeled heparin binding to FGF-

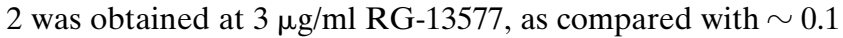
$\mu \mathrm{g} / \mathrm{ml}$ unlabeled heparin (Fig. 1). Likewise, $50 \%$ inhibition of ${ }^{125} \mathrm{I}-\mathrm{FGF}-2$ binding to HS in a naturally produced subendothelial extracellular matrix was obtained in the presence of $2 \mu \mathrm{g} / \mathrm{ml}$ RG-13577, as compared with $0.2 \mu \mathrm{g} / \mathrm{ml}$ heparin (not shown).

Binding of FGF-2 to soluble and cell-surface FGFR1 is enhanced by heparin/HS or by heparin-derived oligosaccharides containing eight or more sugar residues $(25,39)$. Unlike heparin, compound RG-13577 alone failed to stimulate FGF-2

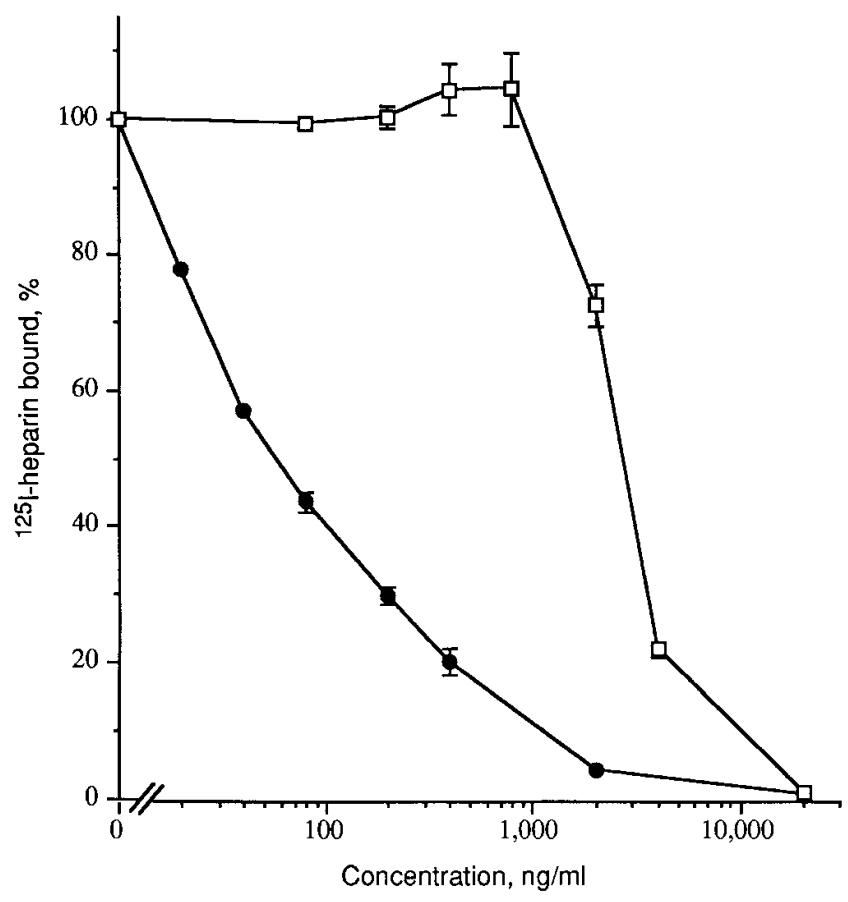

Figure 1. RG-13577 inhibits binding of heparin to FGF-2. ${ }^{125}$ I-heparin was incubated $\left(2 \mathrm{~h}, 4^{\circ} \mathrm{C}\right)$ with FGF-2 $(4 \mathrm{nM} ; 72 \mathrm{ng} / \mathrm{ml})$ in the absence or presence of increasing concentrations of RG-13577 ( $\square$ ) or unlabeled heparin $(\bullet)$. Complexes were immunoprecipitated with a 1:250 dilution of monoclonal anti-FGF-2 antibody (DG2) and protein A-Sepharose. Unbound ${ }^{125} \mathrm{I}$-heparin was removed by washing $(2 \times)$ with PBS, and the immobilized ${ }^{125}$ I-heparin was counted in a gamma counter. Each data point represents the mean \pm SD of triplicate samples.

binding to soluble FGFR1-alkaline phosphatase fusion protein (Fig. $2 A$ ) and to FGFR1 on HS-deficient CHO-pgsA-745-flg cells (Fig. 2 B). Moreover, in both systems, RG-13577, at concentrations higher than $1 \mu \mathrm{g} / \mathrm{ml}$, inhibited the stimulatory effect of heparin on FGF-2 receptor binding. Interestingly, a significant $(\sim 60 \%)$ enhancement with heparin in stimulating FGF-2 binding to FGFR1-alkaline phosphatase fusion protein was observed in the presence of both a suboptimal concentration $(20 \mathrm{ng} / \mathrm{ml})$ of heparin and low concentrations (up to $1 \mu \mathrm{g} /$ ml) of RG-13577 (Fig. 2 A). At high concentrations of RG$13577(>20 \mu \mathrm{g} / \mathrm{ml})$, a three- to fourfold increased FGF-2 receptor binding, relative to the basal binding in the presence of FGF-2 alone, was observed (not shown). This apparently nonspecific binding may be due to aggregation or denaturation of FGF-2 in the presence of a large excess of RG-13577.

Effect of RG-13577 on FGF-2 and FGFR1 dimerization. Ligand-induced receptor dimerization is a key event in transmembrane signaling by receptors with tyrosine kinase activity. Heparin binds to acidic and basic FGF in a multivalent manner, resulting in their oligomerization $(14,25)$. The FGF-heparin complex can then bind to at least two receptor molecules, leading to FGF receptor dimerization, activation, and signal transduction (14). We investigated the effect of RG-13577 on heparin-mediated dimerization of FGF-2. For this purpose, ${ }^{125} \mathrm{I}-\mathrm{FGF}-2$ was incubated in the absence and presence of heparin, with or without increasing concentrations of compound RG-13577. The reaction mixture was then subjected to cross- 

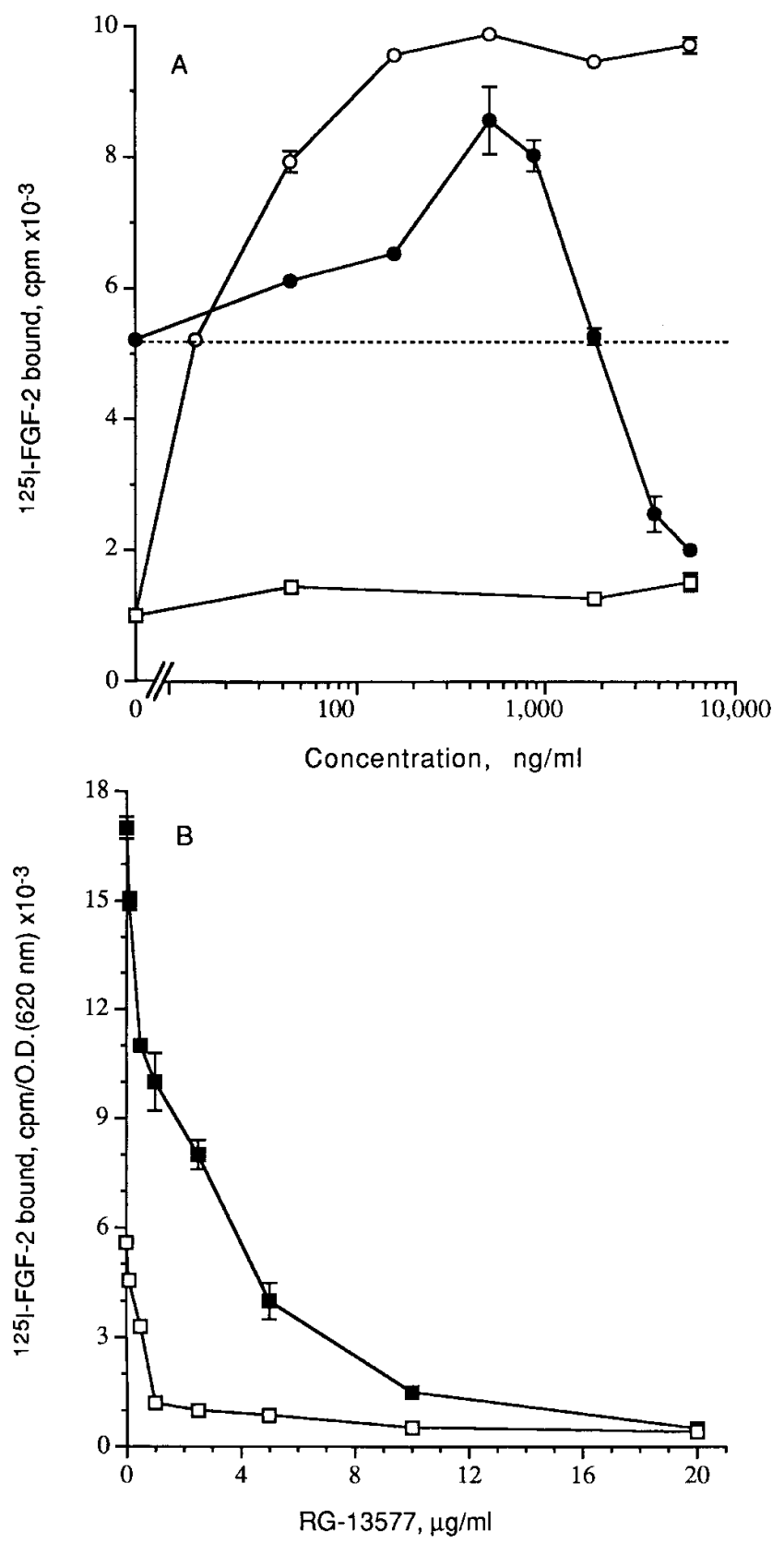

Figure 2. RG-13577 inhibits FGF-2 binding to FGFR-1. (A) Soluble receptor binding: FRAP-conditioned medium was incubated $(2 \mathrm{~h}$, $4^{\circ} \mathrm{C}$ ) with ${ }^{125} \mathrm{I}-\mathrm{FGF}-2$ in the presence of increasing concentrations of heparin (O) or RG-13577 ( $\square$ ). FRAP-conditioned medium was also incubated with increasing concentrations of RG-13577 in presence of $20 \mathrm{ng} / \mathrm{ml}$ heparin ( $)$. The bound FRAP-FGF-2 complexes were immunoprecipitated with anti-alkaline phosphatase monoclonal antibodies coupled to Sepharose, followed by washing with PBS. ${ }^{125} \mathrm{I}-$ FGF-2 receptor binding was determined by counting the tubes in a gamma counter. Each data point represents the mean \pm SD of triplicate samples. The dashed line represents FGF-2 receptor binding activity in presence of $20 \mathrm{ng} / \mathrm{ml}$ heparin. Any activity above this line indicates a synergistic effect of RG-13577, while points below the line represent an inhibitory effect. $(B)$ Cell-surface receptor binding: CHO-pgsA-745-flg cells were incubated $\left(2 \mathrm{~h}, 4^{\circ} \mathrm{C}\right)$ with $1 \mathrm{ng} / \mathrm{ml}{ }^{125} \mathrm{I}-$ FGF-2, with or without increasing concentrations of RG-13577, in the absence $(\square)$ or presence of $200 \mathrm{ng} / \mathrm{ml}$ heparin ( $\square)$. The amount of radioactivity specifically bound to high-affinity binding sites was determined as described in Methods. Each data point represents the mean \pm SD of four culture wells.

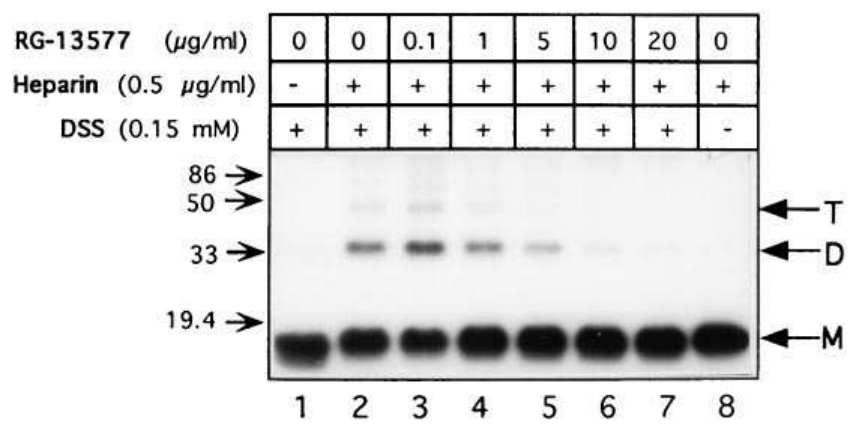

Figure 3. Effect of RG-13577 on heparin-mediated dimerization of FGF-2. ${ }^{125} \mathrm{I}-\mathrm{FGF}-2(20 \mathrm{ng} / \mathrm{ml})$ was incubated $\left(1 \mathrm{~h}, 24^{\circ} \mathrm{C}\right)$ in the absence (lane 1) and presence (lanes 2-8) of heparin $(0.5 \mu \mathrm{g} / \mathrm{ml})$ and increasing concentrations $(0.1-20 \mu \mathrm{g} / \mathrm{ml}$ ) of RG-13577 (lanes 3-7). DSS was then added to a final concentration of $0.15 \mathrm{mM}$ and the crosslinking reaction was quenched with ethanolamine- $\mathrm{HCl}$, as described in Methods. The cross-linked ${ }^{125}$ I-FGF-2 was detected by $15 \%$ SDSPAGE and autoradiography. M, monomer; D, dimer; T, trimer. Molecular weight markers are in kilodaltons.

linking and SDS-PAGE. While in the absence of heparin, only the monomeric form of FGF-2 was detected (Fig. 3, lane 1), addition of heparin resulted in formation of FGF-2 dimers, trimers, and tetramers (Fig. 3, lane 2). Unlike heparin, compound RG-13577 alone failed to induce dimerization of FGF-2 (not shown). Moreover, as demonstrated in Fig. 3, RG-13577 abrogated the dimerizing effect of heparin. Thus, $10 \mu \mathrm{g} / \mathrm{ml}$ RG-13577 markedly inhibited formation of FGF-2 dimers and trimers obtained in the presence of $0.5 \mu \mathrm{g} / \mathrm{ml}$ heparin (Fig. 3, lane 6). Partial inhibition of FGF-2 dimerization was observed

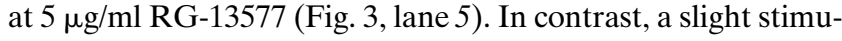
lation of heparin-mediated FGF-2 oligomerization was ob-

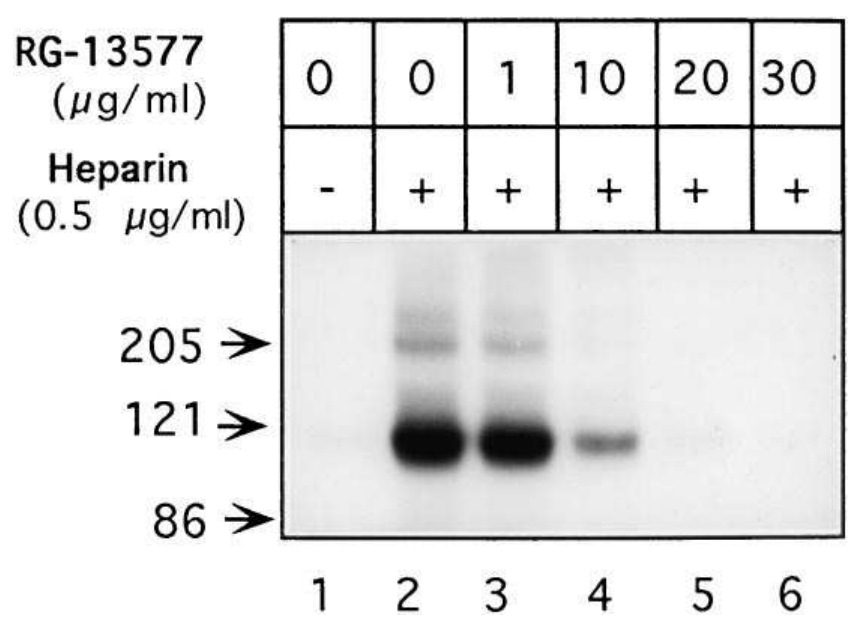

Figure 4. RG-13577 inhibits heparin-mediated FGF-2-receptor cross-linking and dimerization. Confluent HS-deficient CHOpgs A 745-flg cells were incubated $\left(2 \mathrm{~h}, 4^{\circ} \mathrm{C}\right)$ with $1 \mathrm{ng} / \mathrm{ml}{ }^{125} \mathrm{I}-\mathrm{FGF}-2$ in the absence (lane 1) or presence (lanes 2-6) of $0.5 \mu \mathrm{g} / \mathrm{ml}$ heparin and increasing concentrations (1-30 $\mu \mathrm{g} / \mathrm{ml}$ ) of RG-13577 (lanes 3-6). Unbound ${ }^{125}$ I-FGF- 2 was removed and the cells were washed $(3 \times)$. The cells were then incubated with $0.3 \mathrm{mM}$ DSS, quenched with $150 \mathrm{mM}$ glycine, $2 \mathrm{mM}$ EDTA, lysed, and subjected to a $7.5 \%$ SDS-PAGE and autoradiography, as described in Methods. Molecular weight markers are in kilodaltons. 
tained in the presence of $0.1 \mu \mathrm{g} / \mathrm{ml} \mathrm{RG-13577} \mathrm{(Fig.} \mathrm{3,} \mathrm{lane} \mathrm{3).}$ In subsequent experiments, HS-deficient $\mathrm{CHO}$ cells overexpressing FGFR1 (CHO-pgsA-745-flg) were incubated with ${ }^{125}$ I-FGF-2 in the absence and presence of heparin and increasing concentrations of RG-13577. The cultures were then subjected to cross-linking, SDS-PAGE, and autoradiography. As demonstrated in Fig. 4, FGF-2 receptor binding and dimerization occurred in the presence (Fig. 4, lane 2), but not absence (Fig. 4, lane 1) of heparin. Heparin-mediated FGFR binding and dimerization were slightly inhibited in the presence of 1 $\mu \mathrm{g} / \mathrm{ml}$ RG-13577 (Fig 4, lane 3), while $10 \mu \mathrm{g} / \mathrm{ml} \mathrm{RG-13577} \mathrm{par-}$ tially inhibited FGF-2 receptor binding and to a higher extent receptor dimerization (Fig 4, lane 4). At higher concentrations, RG-13577 almost completely inhibited both receptor binding and dimerization (Fig. 4, lanes 5 and 6).

Effect of RG-13577 on FGF-2-induced tyrosine phosphorylation. In intact cells, heparin or HS promotes FGF-1 and
FGF-2 stimulation of FGFR dimerization, tyrosine kinase activation, and signaling via FGFRs $(14,25,27,38)$. We investigated the effect of RG-13577 on FGF-2-induced tyrosine phosphorylation in Balb/c 3T3 fibroblasts. For this purpose, growth-arrested subconfluent cells were preincubated with increasing concentrations of RG-13577 followed by exposure to FGF-2. The cells were then lysed and subjected to SDS-PAGE and immunoblot detection of tyrosine-phosphorylated proteins. FGF-2 stimulated tyrosine phosphorylation of several cellular proteins, the most prominent of which were proteins of 42, 44, 90, and $145 \mathrm{kD}$ (Fig. $5 \mathrm{~A}$, lane 5), corresponding to p42 ${ }^{\text {mapk }}, \mathrm{p} 44^{\text {mapk }}, \mathrm{p} 90$, and FGFR1, respectively, as revealed by reprobing the membranes with antibodies directed against MAPK or p90/80K-H (31) (data not shown), and by immunoprecipitation of cell lysates with anti-FGFR1 antibodies (Fig. 5 $B)$. Similar results were obtained with BAEC, although the effect of FGF-2 was less prominent due to a high level of basal

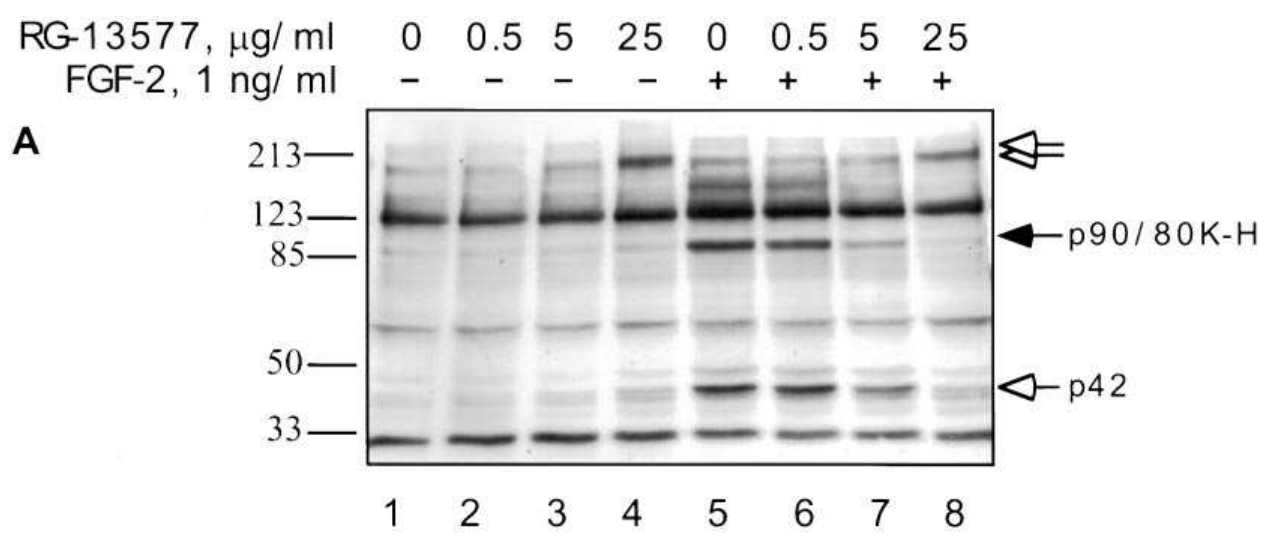

$\begin{array}{rrrrrrr}\mathrm{RG}-13577, \mu \mathrm{g} / \mathrm{ml} & 0 & 0 & 0.5 & 5 & 25 \\ \mathrm{FGF}-2,1 \mathrm{ng} / \mathrm{ml} & - & + & + & + & + \\ & 213- \\ & & & & \end{array}$

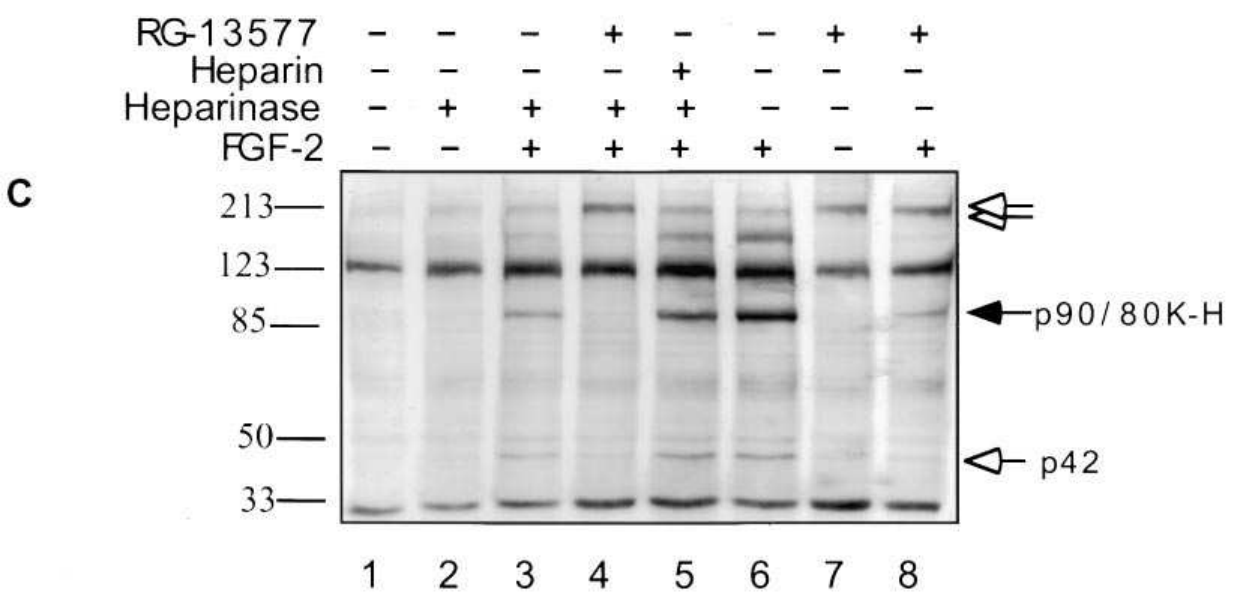

Figure 5. Effect of RG-13577 on FGF-2-induced tyrosine phosphorylation of cellular substrates. Growth-arrested (48 h, $0.5 \%$ FCS) subconfluent Balb/c 3 T3 fibroblasts were exposed to FGF-2 $(1 \mathrm{ng} / \mathrm{ml})$, RG-13577, or both. The cells were lysed and $50 \mu \mathrm{g}$ of the total cellular proteins were separated on $7.5 \%$ SDS-PAGE, immunoblotted with antiphosphotyrosine antibody (PY20) and visualized by ECL, as described in Methods. $(A)$ Dose response. Cells were exposed (10 min, $37^{\circ} \mathrm{C}$ ) to increasing concentrations $(0.5-25 \mu \mathrm{g} / \mathrm{ml})$ of RG-13577 followed by a 10 -min incubation with FGF-2. (B) FGFR1 autophosphorylation. Cells were exposed to RG13577 and FGF-2 as described in $A$. $200 \mu \mathrm{g}$ of total cellular proteins were immunoprecipitated with antibodies directed against FGFR1 and subjected to SDS-PAGE and immunoblotting with PY-20. (C) Effect of heparinase treatment. Cells were either pretreated (lanes $2-5)(1 \mathrm{~h}$, $37^{\circ} \mathrm{C}$ ) or untreated (lanes $1,6-8$ ) with bacterial heparinases (a mixture of heparinase I, II, and III; 0.1 $\mathrm{U} / \mathrm{ml}$ each). The cells were then exposed $\left(10 \mathrm{~min}, 37^{\circ} \mathrm{C}\right)$ to $\mathrm{FGF}-2$ (lanes 3-6,8) in the absence (lanes $1-3,5,6)$ or presence (lanes $4,7,8$ ) of $10 \mu \mathrm{g} / \mathrm{ml}$ RG-13577. Heparin $(1 \mu \mathrm{g} / \mathrm{ml})$ was added to some of the cells (lane 5). Total cell lysates were subjected to SDS-PAGE and immunoblotting with PY-20 antibodies. The position of molecular size standards is indicated. 
phosphorylation, as compared with growth-arrested Balb/c 3T3 fibroblasts. Tyrosine phosphorylation of these proteins was not affected by heparin (up to $75 \mu \mathrm{g} / \mathrm{ml}$ ) (data not shown), but was partially inhibited in the presence of $5 \mu \mathrm{g} / \mathrm{ml} \mathrm{RG-}$ 13577 (Fig. $5 A$, lane 7), with an almost complete inhibition at

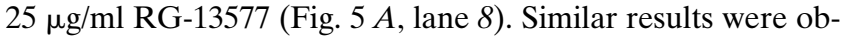
tained regardless of whether RG-13577 was added before FGF-2, or when both FGF-2 and RG-13577 were added at the same time (not shown). Addition of RG-13577 after exposing cells to FGF-2 failed to affect the pattern of FGF-2-induced tyrosine phosphorylation. The basal phosphorylation in the absence of exogenously added FGF-2 was not affected by RG13577 (Fig. 5 A, lanes 2-4), except that tyrosine phosphorylation of an $\sim 200 \mathrm{kD}$ protein (p200) was stimulated in the presence of $5 \mu \mathrm{g} / \mathrm{ml} \mathrm{RG}-13577$ and to a higher extent in cells

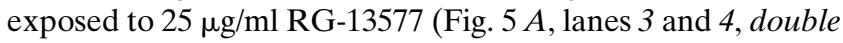
arrow). This stimulation was observed $10 \mathrm{~min}$ after the addition of RG-13577, reaching a plateau by 20 min incubation (not shown). Heparin (up to $75 \mu \mathrm{g} / \mathrm{ml}$ ) failed to induce tyrosine phosphorylation of p200 and to inhibit its phosphorylation in the presence of RG-13577.

In an attempt to investigate whether the effect of RG13577 is dependent on cellular HS, growth-arrested 3T3 fibroblasts were pretreated $\left(1 \mathrm{~h}, 37^{\circ} \mathrm{C}\right)$ with bacterial heparinases (a mixture of heparinase I, II, and III; $0.1 \mathrm{U} / \mathrm{ml}$ each) (Fig. 5 C). Metabolic labeling with $\mathrm{Na}_{2}{ }^{35} \mathrm{SO}_{4}$ revealed that under these conditions, $>90 \%$ of the cell surface HS was degraded by the bacterial enzymes. The cells were then washed, exposed (10 $\left.\min , 37^{\circ} \mathrm{C}\right)$ to FGF-2 $(1 \mathrm{ng} / \mathrm{ml})$ in the absence (Fig. $5 \mathrm{C}$, lane 3 ) or presence (Fig. 5 C, lane 4) of $10 \mu \mathrm{g} / \mathrm{ml} \mathrm{RG-13577} \mathrm{and} \mathrm{ana-}$ lyzed for tyrosine phosphorylation of cellular proteins. The stimulatory effect of FGF-2 was less pronounced in heparinase-treated cells (Fig. 5 C, lane 3) and was restored upon the addition of $1 \mu \mathrm{g} / \mathrm{ml}$ heparin (Fig. 5 C, lane 5). RG-13577 completely inhibited tyrosine phosphorylation of p90 and FGFR1 after heparinase treatment (Fig. $5 C$, lane 4 ), as compared with a partial inhibition in untreated cells (Fig. $5 C$, lane 8 ). In contrast, there was little or no effect of heparinase on tyrosine phosphorylation of p200, which is FGF-2 independent (Fig. 5 $C$, lane 4). These results suggest that RG-13577 competes with the cell surface HS on interaction with FGF-2, resulting in a more effective inhibition of cellular responses to FGF-2 in the absence of HS.

Next, we investigated the effect of RG-13577 on FGFR1 autophosphorylation. Both direct and indirect approaches were applied. The Balb/c 3T3 cells were stimulated with FGF-2 and cell lysates were subjected to immunoprecipitation with an antibody against the cytoplasmic domain of FGFR1, followed by SDS-PAGE and immunoblot detection (anti-phosphotyrosine PY-20 antibodies) of tyrosine-phosphorylated proteins. FGF-2-induced receptor autophosphorylation was inhibited in cells exposed to $5-25 \mu \mathrm{g} / \mathrm{ml} \mathrm{RG-13577} \mathrm{(Fig.} 5$ B). Heparin failed to inhibit FGFR-1 phosphorylation even at $75 \mu \mathrm{g} / \mathrm{ml}$ (not shown). In other experiments, 3T3 cells were first incubated with ${ }^{125}$ I-FGF-2 in the absence and presence of RG13577, heparin, or excess unlabeled FGF-2. The cells were then subjected to cross-linking and immunoprecipitation with the PY-20 antibody, followed by SDS-PAGE and autoradiography (Fig. 6, lanes 1-4). FGFR autophosphorylation (both the monomeric and dimeric forms) was completely inhibited in the presence of $25 \mu \mathrm{g} / \mathrm{ml}$ of RG-13577 (Fig. 6, lane 2), while heparin had a stimulatory effect (Fig. 6, lane 3). It should be

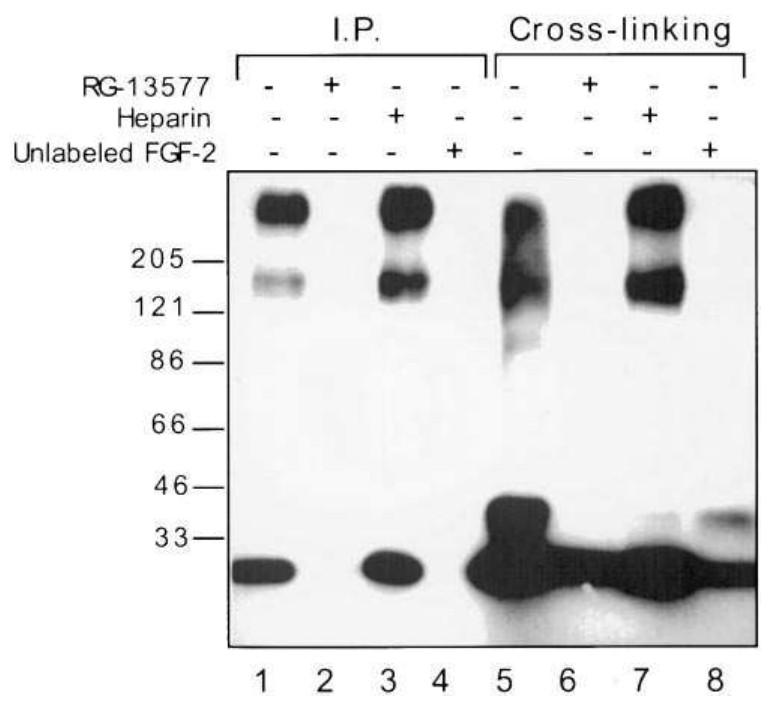

Figure 6. RG-13577 inhibits FGF-2 receptor cross-linking, dimerization, and phosphorylation in 3T3 fibroblasts. Growth-arrested Balb/c $3 \mathrm{~T} 3$ cells were incubated $\left(10 \mathrm{~min}, 37^{\circ} \mathrm{C}\right)$ with $1 \mathrm{ng} / \mathrm{ml}{ }^{125} \mathrm{I}-\mathrm{FGF}-2$ in the absence (lanes 1, 3-5, 7,8) and presence (lanes, 2 and 6 ) of $25 \mu \mathrm{g} /$ $\mathrm{ml} \mathrm{RG-13577.} \mathrm{Heparin}(75 \mu \mathrm{g} / \mathrm{ml})$ was added to some of the cultures (lanes 3 and 7). The cells were then subjected to cross-linking as described in Fig. 4. Aliquots of the cell lysates were then immunoprecipitated with PY-20 antibodies, as described in Methods. Samples of the total cell lysates (lanes 5-8) and immunoprecipitates (lanes 1-4) were subjected to a $7.5 \%$ SDS-PAGE and autoradiography. Molecular weight markers are in kilodaltons.

noted that the dimeric form of FGFR1 is phosphorylated to a much higher extent as compared with the monomeric form. Cross-linking experiments that were not followed by immunoprecipitation (Fig. 6, lanes 5-8) revealed that under the same conditions, RG-13577 completely inhibited dimerization of both FGF-2 and FGF-2-FGFR complexes (Fig. 6, lane 6). In contrast, FGFR1 dimerization was stimulated in the presence of heparin (Fig. 6, lane 7).

Effect of RG-13577 on FGF-2-induced mitogenic activity. A cytokine-dependent lymphoid cell line $\left(\mathrm{BaF}_{3}\right)$ engineered to express FGFR1 (25) was applied to investigate the effect of RG-13577 on FGF-2-mediated cell proliferation. These cells (clone F32) respond to FGF-2 only in the presence of exogenously added species of heparin, HS, heparin-derived oligosaccharides, and certain unrelated molecules $(12,25,27)$. Unlike heparin, compound RG-13577 alone failed to stimulate DNA synthesis by F32 cells in response to FGF-2. Moreover, RG$13577(20-40 \mu \mathrm{g} / \mathrm{ml})$ inhibited the stimulatory effect of heparin (Fig. 7). A synergistic effect was however obtained at low concentrations of heparin (10-100 ng/ml) and RG-13577 (up to 10 $\mu \mathrm{g} / \mathrm{ml}$ ), accompanied by an inhibition of the growth-promoting effect of heparin at concentrations of RG-13577 higher than 20 $\mu \mathrm{g} / \mathrm{ml}$ (Fig. 7). For example, a nearly 10 -fold stimulation of ${ }^{3} \mathrm{H}$ thymidine incorporation was obtained when the F32 cells were exposed to FGF-2 and both heparin (10 ng/ml) and RG-13577 $(5 \mu \mathrm{g} / \mathrm{ml})$, but there was no effect in the presence of either 10 $\mathrm{ng} / \mathrm{ml}$ heparin alone, or $5 \mu \mathrm{g} / \mathrm{ml} \mathrm{RG-13577}$ alone. Likewise, a slight (two- to threefold) stimulation of FGF-2-mediated DNA synthesis was obtained in the presence of $100 \mathrm{ng} / \mathrm{ml}$ heparin alone, as compared with a 15 -fold stimulation in the presence 


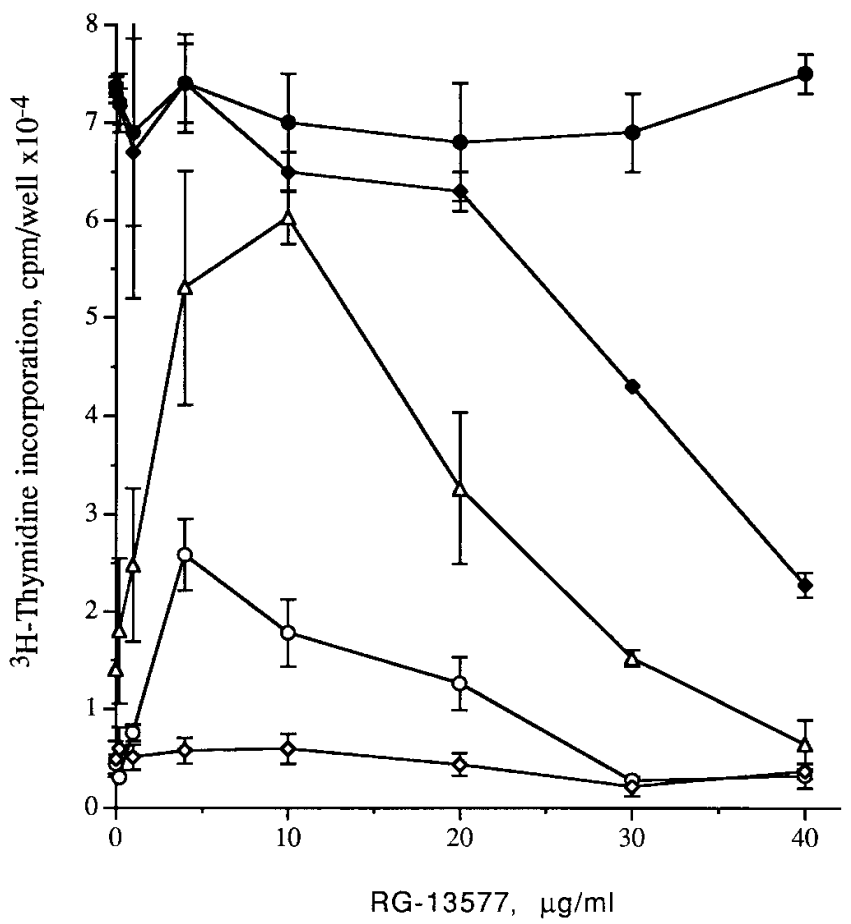

Figure 7. Effect of RG-13577 and heparin on FGF-2-induced proliferation of FGFR1-transfected $\mathrm{BaF}_{3}$ (F32) cells. F32 cells were incubated $\left(48 \mathrm{~h}, 37^{\circ} \mathrm{C}\right)$ in $96-w e l l$ plates in the presence of $3 \mathrm{ng} / \mathrm{ml} \mathrm{FGF-2}$ and increasing concentrations of RG-13577 in the absence $(\diamond)$ or presence of increasing amounts of heparin $(O, 10 \mathrm{ng} / \mathrm{ml} ; \triangle, 100 \mathrm{ng} / \mathrm{ml}$; $\bullet, 1 \mu \mathrm{g} / \mathrm{ml} ; \bullet, 5 \mu \mathrm{g} / \mathrm{ml}) .{ }^{3} \mathrm{H}$-Thymidine $(1 \mu \mathrm{Ci} /$ well $)$ was added $48 \mathrm{~h}$ after seeding, and $6 \mathrm{~h}$ later the cells were collected with a cell harvester. Thymidine incorporation was determined by liquid scintillation counting, as described in Methods. Each data point represents the mean $\pm \mathrm{SD}$ of three culture wells.

of both heparin (100 ng/ml) and RG-13577 (10 $\mathrm{g} / \mathrm{ml})$ (Fig. 7). Under these conditions, ${ }^{3} \mathrm{H}$-thymidine incorporation was nearly maximal, similar to that observed in the presence of FGF-2 and $1 \mu \mathrm{g} / \mathrm{ml}$ heparin alone. At this concentration of heparin, RG-13577 failed to exert any stimulatory effect, but rather inhibited the mitogenic effect of FGF-2. The inhibitory effect of RG-13577 (up to $40 \mu \mathrm{g} / \mathrm{ml}$ ) was prevented in the presence of $5 \mu \mathrm{g} / \mathrm{ml}$ heparin (Fig. 7), indicating that the antiproliferative effect of RG-13577 is not due to a toxic effect.

We tested the effect of RG-13577 on FGF-2-induced ${ }^{3} \mathrm{H}$ thymidine incorporation by the Balb/c 3T3 cells. $50 \%$ inhibition of FGF-2-stimulated DNA synthesis was observed in the presence of $5 \mu \mathrm{g} / \mathrm{ml} \mathrm{RG-13577} \mathrm{(Fig.} 8$ A), in correlation with its effect on tyrosine phosphorylation. Altogether, these studies, performed with a single cell line (Balb/c 3T3), suggest that the antiproliferative effect of compound RG-13577 is due to an inhibition of FGFR dimerization, autophosphorylation, and signaling. In subsequent experiments, we investigated the effect of RG-13577 on BAEC proliferation. Unlike the F32 cells, these cells express abundant cell surface HS and hence respond well to FGF-2 in the absence of exogenously supplied heparin. Sparsely seeded BAECs were maintained in the absence and presence of increasing concentrations of RG-13577, with or without FGF-2. $3 \mathrm{~d}$ after seeding, the cells were exposed $(3 \mathrm{~h})$ to ${ }^{3} \mathrm{H}$-thymidine for measurements of DNA syn- thesis. A significant inhibition of ${ }^{3} \mathrm{H}$-thymidine incorporation

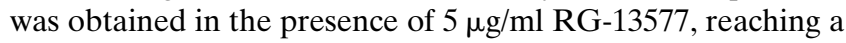
nearly complete inhibition at 10 and $20 \mu \mathrm{g} / \mathrm{ml}$, in the absence and presence of FGF-2, respectively (Fig. $8 \mathrm{~B}$ ). Under these conditions, lack of cytotoxicity was revealed by the exclusion of trypan blue by $>90 \%$ of the cells, as well as by the lack of chromatin fragmentation and condensation revealed by DAPI staining. The antiproliferative effect of RG-13577 was also demonstrated when the BAECs were seeded at a clonal cell density in the absence and presence of $1 \mathrm{ng} / \mathrm{ml} \mathrm{FGF-2,} \mathrm{with} \mathrm{or}$ without RG-13577. Under these conditions, there was little or no proliferation of BAECs in the absence of FGF-2 (Fig. $8 B$, inset $B$ ) and an almost complete inhibition of FGF-2-stimulated cell proliferation in the presence of $25 \mu \mathrm{g} / \mathrm{ml} \mathrm{RG-13577}$ (Fig $8 B$, inset $E$ ).

Effect of RG-13577 on microvessel formation. The effect of compound RG-13577 on microvessel formation was investigated using rat aortic rings embedded in a collagen gel and maintained under culture conditions in a serum-free medium. Branching microvessels forming a capillary network of tubes and loops were developed at the periphery of untreated aortic rings, starting on days 5-7 and reaching a maximal degree of sprouting on days 12-15 (Fig. $9 \mathrm{~A}, I$ ). In contrast, microvessel formation was completely inhibited in the presence of RG13577. Under this condition, single cells (30-40\% of which positively stained for von Willebrand factor) were migrating out of the aortic ring, but failed to align into microvessel tubes (Fig. $9 A, I I$ ). A quantitative analysis of the number of outgrowing microvessels revealed a significant inhibitory effect of RG-13577 already at $0.1 \mu \mathrm{g} / \mathrm{ml}$ and an almost complete inhibi-

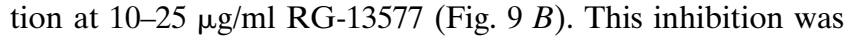
reversible as indicated by normal out-growth of capillary tubes after removal of the compound $2 \mathrm{~d}$ after its addition (not shown). Removal of the drug on day 6 failed to elicit microvessel formation evaluated $6 \mathrm{~d}$ afterwards. It is assumed that microvessel formation in this system is due to endogenous FGF-2 and other angiogenic factors that are stored in the tissue (21, 40). These growth factors are released in response to tissue damage and their angiogenic and growth-promoting activity is inhibited by a polyanionic, heparin-mimicking compound such as RG-13577.

\section{Discussion}

A dual receptor mechanism involving HS and tyrosine kinase receptors operates in signal transduction and cell proliferation induced by various heparin-binding growth factors, such as FGF-2 $(4,5,23)$. The role of heparin/HS in FGF-2 signaling has attracted extensive research aimed at identifying potent mimetics that can suppress abnormal FGF signaling in diseases such as atherosclerosis or in neoplasia by inhibiting the process of angiogenesis that supports solid tumor growth $(3,10,15$, 41). The results of the present study show that a synthetic polyanionic aromatic compound (RG-13577, poly-4-hydroxyphenoxy acetic acid) is capable of inhibiting FGF-2-induced endothelial cell proliferation and microvessel formation. This compound mimics some of the functional properties of heparin, but exerts only $\sim 1 \%$ of its anticoagulant activity (17). RG-13577 interacts directly with FGF-2 as demonstrated by its ability to inhibit the binding of ${ }^{125}$ I-heparin to FGF-2. An excess amount of compound RG-13577 also abrogated the ability of heparin to promote FGF-2 binding to FGFR1, either in a 

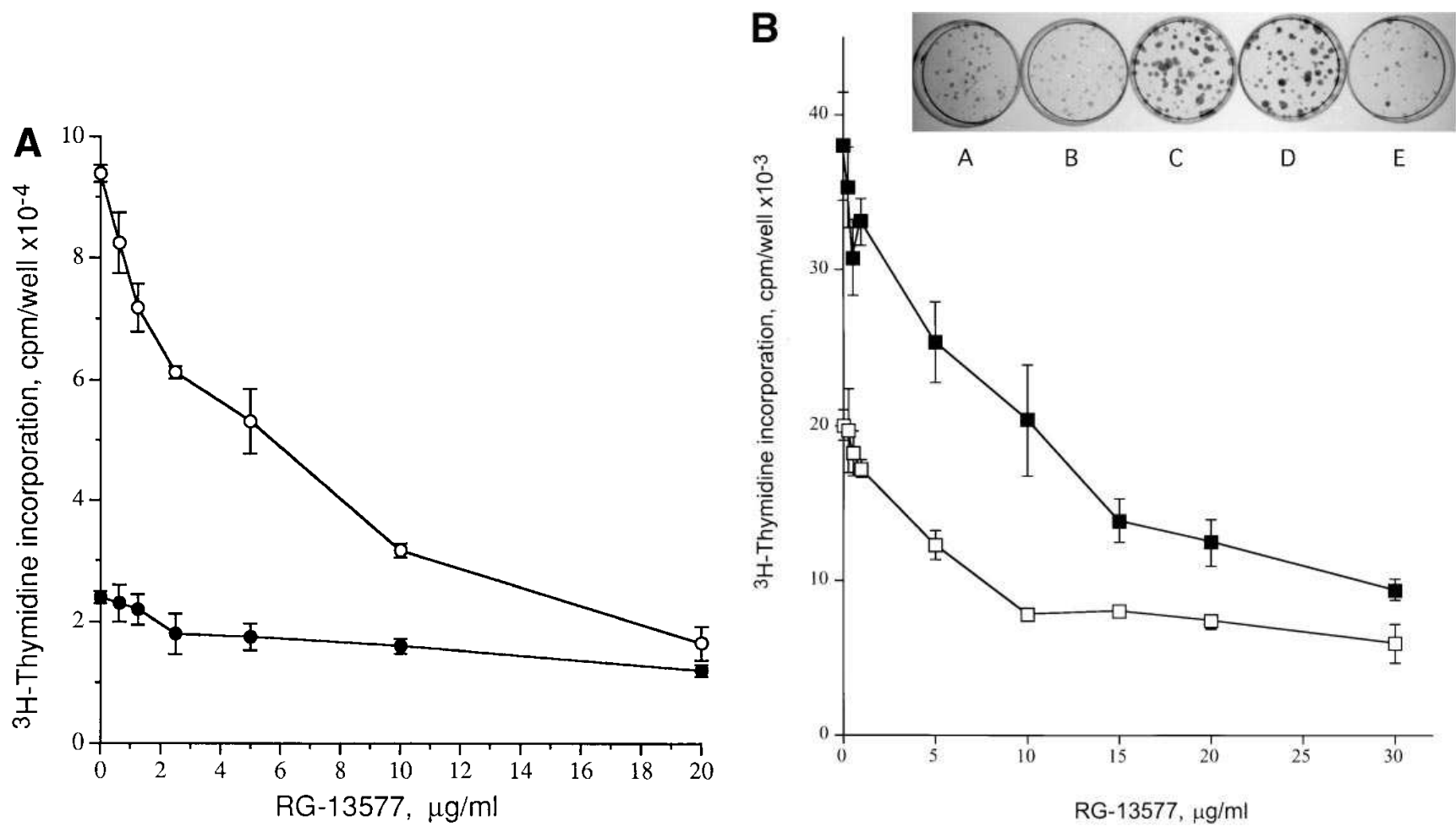

Figure 8. Effect of RG-13577 on proliferation of 3 T3 fibroblasts and vascular endothelial cells. $(A)$ Balb/c 3 T3 fibroblasts. Increasing concentrations of RG-13577 were added to growth-arrested $3 \mathrm{~T} 3$ cells in the absence $(\bullet)$ or presence $(\bigcirc)$ of $1 \mathrm{ng} / \mathrm{ml} \mathrm{FGF-2.}{ }^{3} \mathrm{H}-\mathrm{Thymidine}(0.5 \mu \mathrm{Ci} / \mathrm{well})$ was added for $48 \mathrm{~h}$ and the cells were harvested and measured for DNA synthesis. $(B)$ Vascular endothelial cell. BAECs were seeded (1,000 cells/16-mm well) in DMEM containing $10 \%$ heat-inactivated calf serum. $1 \mathrm{~d}$ after seeding, the medium was replaced by fresh medium containing various concentrations of RG-13577 in the absence $(\square)$ and presence $(\square)$ of $1 \mathrm{ng} / \mathrm{ml} \mathrm{FGF-2.} 3 \mathrm{~d}$ later, the cells were exposed $\left(3 \mathrm{~h}, 37^{\circ} \mathrm{C}\right)$ to ${ }^{3} \mathrm{H}$-thymidine $(5 \mu \mathrm{Ci} /$ well) and DNA synthesis was determined by measuring the radioactivity incorporated in TCA-insoluble material. Each data point (counts per minute/well) is the mean \pm SD of 4 wells. (Inset) BAECs were seeded at a clonal density (300 cells/35-mm dish) in DMEM containing $10 \%$ heat-inactivated calf serum. $1 \mathrm{~d}$ later and every other day afterwards, the medium was replaced with fresh medium without $(A$ and $B$ ) or with $(C-E) 1 \mathrm{ng} / \mathrm{ml}$ of FGF-2, in the absence $(A$ and $C$ ) or presence of RG-13577 $(B, 25 \mu \mathrm{g} / \mathrm{ml} ; D, 5 \mu \mathrm{g} / \mathrm{ml} ; E, 25 \mu \mathrm{g} / \mathrm{ml}) .10 \mathrm{~d}$ after seeding, cell colonies were fixed and stained with $0.1 \%$ crystal violet.

soluble form or on the surface of HS-deficient $\mathrm{CHO}$ cells. Unlike heparin, compound RG-13577 failed to promote FGF-2 receptor binding in both the soluble and membrane-bound receptor systems. These results suggest that RG-13577 binds to FGF-2 and alters its conformation so that the FGF-2 molecule can no longer properly interact with heparin/HS and its signaling receptor. Hence, the complex of FGF-2 and RG-13577 is biologically inert and FGF-2 is thus largely removed from the system and is no longer bioavailable. RG-13577 may also interact with FGFR, most likely through binding to a putative heparin-binding domain (7), thus blocking heparin-mediated ligand-receptor interaction. Recent studies indicate that heparin/HS may not be absolutely required for FGF binding to FGFR $(38,42)$, but rather induces or stabilizes oligomerization of FGF molecules, resulting in FGFR dimerization, activation, and signaling $(14,25,43)$. Unlike heparin, RG-13577 failed to mediate FGF-2 oligomerization. Moreover, it abrogated the ability of heparin to dimerize both FGF-2 and FGFR. In fact, dimerization of FGFR could not be detected at a concentration of RG-13577, which only partially inhibited FGF-2 receptor binding. Lack of receptor dimerization might, in turn, abrogate signaling as indicated by the inhibition of tyrosine phosphorylation in $3 \mathrm{~T} 3$ cells stimulated with FGF-2 in the presence of RG-13577. Of particular relevance was the pro- found inhibition of tyrosine phosphorylation of FGFR1 itself and of MAPK and p90 proteins, which are all involved and highly phosphorylated in response to FGF-2 $(31,32,44,45)$. Similar results were obtained with $3 \mathrm{~T} 3$ fibroblasts and vascular endothelial cells. Tyrosine phosphorylation was not affected, or slightly stimulated, in the presence of heparin. In intact cells, exogenously supplied heparin has little or no effect on FGF-2 action due to the presence of cellular HS. Likewise, the effect of RG-13577 on intact, HS-expressing cells appears to be heparin independent. An involvement of heparin in FGF1-induced autophosphorylation of FGFR1 was previously demonstrated in HS-deficient $\mathrm{CHO}$ and $\mathrm{BaF}_{3}$ cells, but not in wild-type CHO cells (14). Similarly, involvement of HS on cell surfaces and extracellular matrix in FGF-2 and vascular endothelial growth factor action was best demonstrated after removal or desulfation of HS by heparinase or chlorate $(34,46-48)$. We investigated whether the effect of RG-13577 is dependent on the cell surface HS. For this purpose, $3 \mathrm{~T} 3$ fibroblasts were treated with bacterial heparinases before their exposure to FGF-2 and RG-13577. Tyrosine phosphorylation was completely inhibited by RG-13577 after heparinase treatment, as compared with a partial inhibition in untreated cells. This result indicates that RG-13577 competes with the cell surface HS on FGF-2 binding and hence exerts a more efficient inhibitory 
A
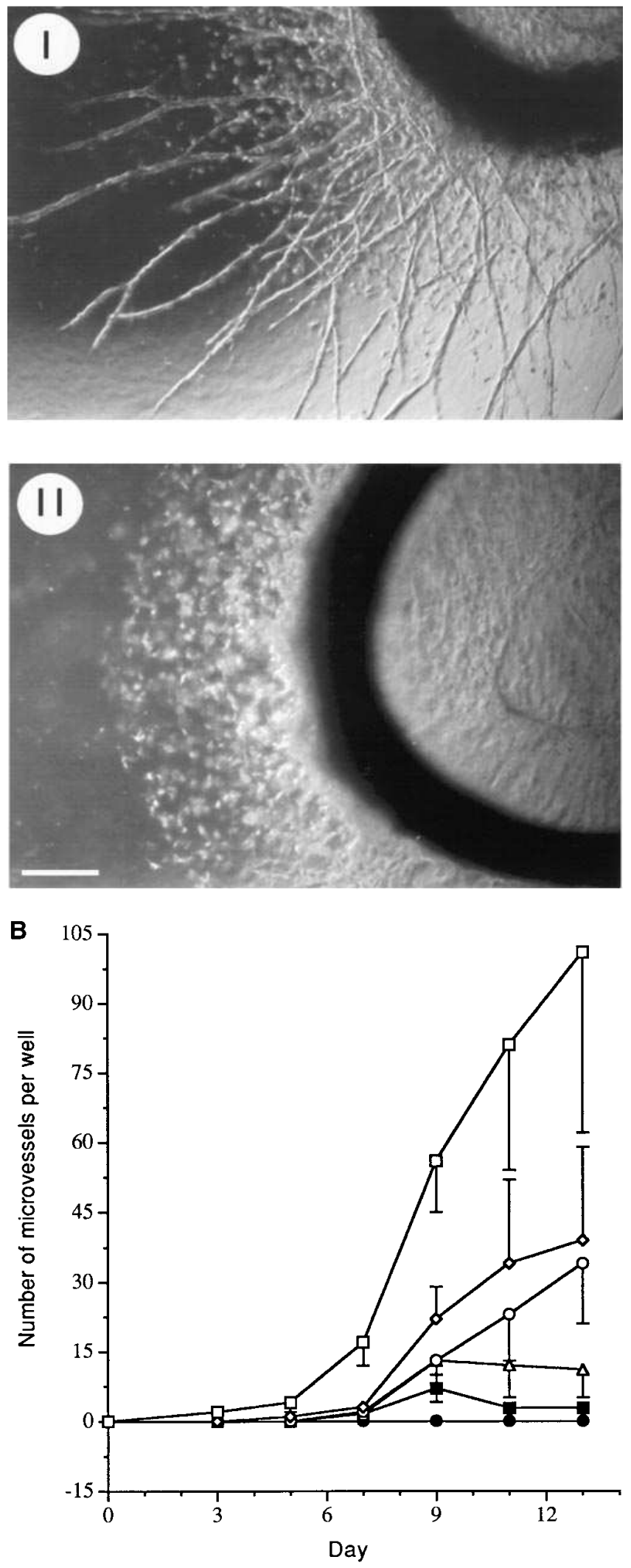

Figure 9. Effect of RG-13577 on microvessel formation in vitro. Rat aortic rings were embedded in the center of type I collagen gel. Serum-free endothelial growth medium was added and replaced every other day. (A) Phase contrast microscopy. Aortic rings were cultured effect in the absence of HS. In contrast, there was no effect of heparinase on tyrosine phosphorylation of p200, which is FGF-2 and heparin/HS independent. In preliminary experiments, we observed a more efficient antiproliferative effect of RG-13577 on HB-EGF (heparin-binding EGF-like growth factor) as compared with FGF-2-induced cell proliferation. We attribute this difference to the lower affinity between HB-EGF and HS and hence the higher ability of RG-13577 to compete with HS on binding to the growth factor. Altogether, it appears that the inhibitory effect of RG-13577 is exerted, at least in part, through competition with the heparin/HS pathway, most likely by masking the heparin-binding domain of FGF-2.

Different cell systems were applied in the present study to demonstrate the effect of RG-13577 on FGF-2 receptor binding, dimerization, tyrosine phosphorylation, and cell proliferation. Each parameter was demonstrated using the most appropriate experimental system. For example, an effect of RG-13577 on FGF cellular binding and receptor dimerization was best demonstrated using HS-deficient CHO cells. 3T3 fibroblasts were applied to demonstrate the effect of RG-13577 on tyrosine phosphorylation, and $\mathrm{BaF}_{3}$ (F32) lymphoid cells were best suited to study stimulatory and inhibitory effects of RG-13577 on cell proliferation. These effects were, however, demonstrated also with a single cell line (i.e., Balb/c 3 T3 fibroblasts), showing that RG-13577 inhibited FGF-2-mediated cell proliferation in correlation with its ability to inhibit FGFR dimerization, tyrosine phosphorylation, and FGF-2-dependent cell proliferation.

Unlike its effect on vascular endothelial and smooth muscle cells, low concentrations of RG-13577 were found to promote FGF-2-mediated proliferation of FGFR1-transfected $\mathrm{BaF}_{3}(\mathrm{~F} 32)$ cells in the presence of suboptimal concentrations of heparin. These cells are devoid of endogenous HS and respond to FGF only when presented with exogenous heparin/ HS (25). Although this cell system is not natural, the synergistic effect of RG-13577 and heparin exemplified the heparin-mimicking nature of RG-13577. Interestingly, low concentrations $(0.1 \mu \mathrm{g} / \mathrm{ml})$ of RG-13577 also slightly stimulated heparin-mediated dimerization of recombinant FGF-2 in a cell-free system. It should be noted that a pronounced inhibition of FGF-2 binding to heparin or FGFR1 and of FGF-2 mitogenic activity was exerted at $2-10 \mu \mathrm{g} / \mathrm{ml} \mathrm{RG-13577.} \mathrm{Low} \mathrm{concentrations} \mathrm{of}$ RG-13577, however, partially stimulated the effect of heparin on FGF-2 dimerization, receptor binding, and growth-promoting activity. These observations suggest that at relatively low concentrations, RG-13577 may bind primarily in the cleft interface between sites 2 and $2^{\prime}$ of adjacent FGF-2 molecules and thus stabilize a dimer configuration $(27,43)$. At high concentrations, the dimer formation is prevented probably due to

$\left(37^{\circ} \mathrm{C}, 12 \mathrm{~d}\right)$ in the absence $(I)$ and presence $(I I)$ of $25 \mu \mathrm{g} / \mathrm{ml}$ RG-13577. Note the formation microvessels branching from the aortic ring in I, as opposed to single viable cells that migrate out of the ring but fail to align into microvessels in the presence of RG-13577 (II). Bar indicates $100-\mu \mathrm{m}$ length. (B) Inhibition of microvessel growth. Aortic rings were incubated in the absence $(\square)$ or presence of increasing concentrations of RG-13577 $(\diamond, 0.1 \mu \mathrm{g} / \mathrm{ml} ; \bigcirc, 1 \mu \mathrm{g} / \mathrm{ml}$; $\Delta, 5 \mu \mathrm{g} / \mathrm{ml} ; \mathbf{\square}, 10 \mu \mathrm{g} / \mathrm{ml} ; \boldsymbol{\bullet}, 25 \mu \mathrm{g} / \mathrm{ml})$. The number of outgrowing microvessels was counted under a phase microscope throughout the course of the experiment. Each data point represents the mean \pm SD of four culture wells. 
competition with heparin binding to sites 1 and $1^{\prime}$ in FGF-2 ("beads on a string" model) and possibly disruption of the crystal packing interface at sites 2 and $2^{\prime}(27,43)$. This effect may lead to the inhibition of receptor signaling and growthpromoting activity.

A conspicuous effect of RG-13577 was a rapid and marked increase in tyrosine phosphorylation of a high molecular weight $(\sim 200 \mathrm{kD})$ cell protein, regardless of the presence of FGF-2 or heparin. Stimulation of tyrosine phosphorylation of several distinct cellular proteins was also observed in prostate cancer cell lines in response to suramin (49). To our knowledge, this effect of suramin and RG-13577 is among the few demonstrations of enhanced tyrosine phosphorylation by nonpeptide chemical compounds. Both suramin $(8-10,41)$ and RG-13577 $(18,19)$ were reported to inhibit the growth-promoting activity of FGF-2 and to reverse FGF-2-mediated cell transformation. Suramin, however, is a sulfated molecule effective at much higher concentrations as compared with RG$13577(9,49)$. Apart from its ability to inhibit FGF-2-stimulated tyrosine phosphorylation, the antiproliferative effect of RG-13577 may also be attributed to tyrosine phosphorylation of a protein (i.e., p200) that serves as a cell surface receptor that may activate an inhibitory signal transduction pathway. In fact, RG-13577 binds to vascular smooth muscle cells in a saturable manner $\left(K_{\mathrm{d}}=\sim 3 \times 10^{-6} \mathrm{M}\right)$, although its putative cell surface receptor has not been identified (19). RG-13577 receptormediated inhibitory pathway may be held responsible for FGF independent inhibition of cell proliferation induced by growthpromoting factors (i.e., thrombin, PDGF) (19), whose signaling is not enhanced by heparin/HS. These results indicate that the mode of action of RG-13577 is more complex than a simple abrogation of certain steps in the FGF-2 signaling cascade. It may modulate the activity of other growth factors and/or exert a direct receptor-mediated inhibitory effect. In some experiments, RG-13577 appeared to exert an inhibitory effect independent of exogenously supplied FGF-2. This effect is likely to be mediated through FGF stored in the tissue (i.e., outgrowth of microvessels from aortic rings), or extracellular matrix deposited by the cells (i.e., basal proliferation of endothelial cells).

Naturally occurring and chemically modified species of heparin may either stimulate or inhibit the mitogenic activity of FGF-2 and other members of the FGF family $(39,50,51)$. It has been demonstrated that an arterial wall-derived, antiproliferative and highly sulfated fragment of HS (52) competes with heparin and effectively inhibits heparin-stimulated binding of FGF-2 to soluble FGFR1 (39). An inhibitory effect was also exerted by sucrose octasulfate (14), suramin $(10,41)$, and ATA (15), the latter two compounds inhibited angiogenesis. Our studies with RG-13577 and related synthetic molecules revealed a general need for two correctly spaced chemical components, a substituted aromatic ring and a negatively charged residue. ATA, suramin, heparin, and RG-13577 show important differences in chemical structure, the most notable being that major polyanionic groups in heparin and suramin are sulfate and sulfonate, respectively, whereas ATA and RG-13577 contain carboxylate groups. Suramin, ATA, and RG-13577 contain a nondegradable backbone, while heparin/HS is sensitive to hydrolytic enzymes. Unlike ATA, whose polymeric structure is undefined (53), RG-13577 is characterized by a substantially ordered linear backbone (17).

The potent antiproliferative effect of RG-13577 on vascular smooth muscle cells (19) and endothelial cells is of poten- tial clinical application in processes such as restenosis, accelerated atherosclerosis, and angiogenesis. In support is the observation that RG-13577 markedly inhibited the outgrowth of microvessels from aortic rings embedded in a collagen gel. Studies are underway to elucidate the inhibitory effect of RG13577 on angiogenesis and restenosis in experimental animal models.

\section{Acknowledgments}

This work was supported by grants from the German-Israeli Foundation for Scientific Research and Development and from the Israel Science Foundation founded by the Israel Academy of Sciences and Humanities-Centers of Excellence Program (I. Vlodavsky), and by National Institutes of Health grant CA-60673 (D.M. Ornitz).

\section{References}

1. Burgess, W.H., and T. Maciag. 1989. The heparin-binding (fibroblast) growth factor family of proteins. Annu. Rev. Biochem. 58:575-606.

2. Johnson, O.E., and L.T. Williams. 1993. Structural and functional diversity in the FGF receptor multigene family. Adv. Cancer Res. 60:1-41.

3. Rapraeger, A.C. 1995. In the clutches of proteoglycans: how does heparan sulfate regulate FGF binding. Chem. Biol. 2:645-649.

4. Klagsbrun, M., and A. Baird. 1991. A dual receptor system is required for basic fibroblast growth factor activity. Cell. 67:229-231.

5. Schlessinger, J., I. Lax, and M. Lemmon. 1995. Regulation of growth factor activation by proteoglycans: what is the role of the low affinity receptors? Cell. 83:357-360.

6. Saksela, O., D. Moscatelli, A. Sommer, and D.B. Rifkin. 1988. Endothelial cell-derived heparan sulfate binds basic fibroblast growth factor and protects it from proteolytic degradation. J. Cell Biol. 107:743-751.

7. Kan, M., F. Wang, J. Xu, J.W. Crabb, J. Hon, and W.L. McKeehan. 1993. An essential heparin-binding domain in the fibroblast growth factor receptor kinase. Science (Wash. DC). 259:1918-1921.

8. Moscatelli, D., and N. Quarto. 1989. Transformation of NIH 3T3 cells with basic fibroblast growth factor or the hst/K-FGF oncogene causes down regulation of the fibroblast growth factor receptor: reversal of morphological transformation and restoration of receptor number by suramin. J. Cell Biol. 109:2519-2527.

9. Yayon, A., and M. Klagsbrun. 1990. Autocrine transformation by chimeric signal peptide-basic fibroblast growth factor: reversal by suramin. Proc. Natl. Acad. Sci. USA. 87:5346-5350.

10. Gagliardi, A., H. Hadd, and D.C. Collins. 1992. Inhibition of angiogenesis by suramin. Cancer Res. 52:5073-5075.

11. Zugmaier, G., M.E. Lippman, and A. Wellstein. 1992. Inhibition by pentosan polysulfate (PPS) of heparin-binding growth factors released from tumor cells and blockage by PPS of tumor growth in animals. J. Natl. Cancer Inst. 84: 1716-1724.

12. Miao, H.-Q., R. Ishai-Michaeli, T. Peretz, and I. Vlodavsky. 1995. Laminarin sulfate mimics the effects of heparin on smooth muscle cell proliferation and basic fibroblast growth factor-receptor binding and mitogenic activity. $J$. Cell. Physiol. 164:482-490.

13. Szabo, S., P. Vattay, E. Scarbrough, and J. Folkman. 1991. Role of vascular factors, including angiogenesis, in the mechanisms of action of sucralfate. Am. J. Med. 91:158S-160S.

14. Spivak-Kroizman, T., M.A. Lemmon, I. Dikic, J.E. Ladbury, D. Pinchasi, J. Huang, M. Jaye, G. Crumley, J. Schlessinger, and I. Lax. 1994. Heparin-induced oligomerization of FGF molecules is responsible for FGF receptor dimerization, activation, and cell proliferation. Cell. 79:1015-1024.

15. Gagliardi, A.R., and D.C. Collins. 1994. Inhibition of angiogenesis by aurintricarboxylic acid. Anticancer Res. 14:475-479.

16. Folkman, J. 1995. Angiogenesis in cancer, vascular, rheumatoid and other diseases. Nat. Med. 1:27-31.

17. Regan, J., S.A. Ben-Sasson, R. Sabatino, D. Eilat, J.G. Bruno, R. D'Alisa, and M.N. Chang. 1993. Mimicry of biological macromolecules by polyaromatic anionic compounds. J. Bioact. Compat. Polym. 8:317-337.

18. Benezra, M., I. Vlodavsky, A. Yayon, R. Bar-Shavit, J. Regan, M. Chang, and S.A. Ben-Sasson. 1992. Reversal of basic fibroblast growth factormediated autocrine cell transformation by aromatic anionic compounds. Cancer Res. 52:5656-5662.

19. Benezra, M., S.A. Ben-Sasson, J. Regan, M. Chang, R. Bar-Shavit, and I. Vlodavsky. 1994. Antiproliferative activity to vascular smooth muscle cells and receptor binding of heparin-mimicking polyaromatic anionic compounds. Arterioscler. Thromb. 14:1992-1999.

20. Gospodarowicz, D., J. Moran, D. Braun, and C.R. Birdwell. 1976. Clonal growth of bovine vascular endothelial cells in tissue culture: fibroblast 
growth factor as a survival agent. Proc. Natl. Acad. Sci. USA. 73:4120-4124.

21. Vlodavsky, I., J. Folkman, R. Sullivan, R. Fridman, R. Ishai-Michaeli, J. Sasse, and M. Klagsbrun. 1987. Endothelial cell-derived basic fibroblast growth factor: synthesis and deposition into subendothelial extracellular matrix. Proc. Natl. Acad. Sci. USA. 84:2292-2296.

22. Esko, J.D. 1991. Genetic analysis of proteoglycan structure, function and metabolism. Curr. Opin. Cell Biol. 3:805-816.

23. Yayon, A., M. Klagsbrun, J.D. Esko, P. Leder, and D.M. Ornitz. 1991. Cell surface, heparin-like molecules are required for binding of basic fibroblast growth factor to its high affinity receptor. Cell. 64:841-848.

24. Miao, H.-Q., T.A. Fritz, J.D. Esko, J. Zimmermann, A. Yayon, and I. Vlodavsky. 1995. Heparan sulfate primed on beta-D-xylosides restores binding of basic fibroblast growth factor. J. Cell. Biochem. 57:173-184.

25. Ornitz, D.M., A. Yayon, J.G. Flanagan, C.M. Svahn, E. Levi, and P. Leder. 1992. Heparin is required for cell-free binding of basic fibroblast growth factor to a soluble receptor and for mitogenesis in whole cells. Mol. Cell. Biol. 12:240-247.

26. Glabe, C.G., P.K. Harty, and S.D. Rosen. 1983. Preparation and properties of fluorescent polysaccharides. Anal. Biochem. 130:287-294.

27. Ornitz, D.M., A.B. Herr, M. Nilsson, J. Westman, C.-M. Svahn, and G. Waksman. 1995. FGF binding and FGF receptor activation by synthetic heparan-derived di- and trisaccharides. Science (Wash. DC). 268:432-436.

28. Chellaiah, A.T., D.G. McEwen, S. Werner, J. Xu, and D.M. Ornitz. 1994. Fibroblast growth factor receptor (FGFR) 3. Alternative splicing in immunoglobulin-like domain III creates a receptor highly specific for acidic FGF/ FGF-1. J. Biol. Chem. 269:11620-11627.

29. Moscatelli, D. 1987. High and low affinity binding sites for basic fibroblast growth factor on cultured cells: absence of a role for low affinity binding in the stimulation of plasminogen activator production by bovine capillary endothelial cells. J. Cell Physiol. 13:123-130.

30. Moscatelli, D. 1988. Metabolism of receptor-bound and matrix-bound basic fibroblast growth factor by bovine capillary endothelial cells. J. Cell Biol. 107:753-759.

31. Goh, K.C., Y.P. Lim, S.H. Ong, C.B. Siak, X. Cao, Y.H. Tan, and G. Guy. 1996. Identification of p90, a prominent tyrosine-phosphorylated protein in fibroblast growth factor-stimulated cells, as 80K-H. J. Biol. Chem. 271:58325838.

32. Friesel, R., W.H. Burgess, and T. Maciag. 1989. Heparin-binding growth factor 1 stimulates tyrosine phosphorylation in NIH 3 T3 cells. Mol. Cell. Biol. 9: $1857-1865$.

33. Ishai-Michaeli, R., A. Eldor, and I. Vlodavsky. 1990. Heparanase activity expressed by platelets, neutrophils and lymphoma cells releases active fibroblast growth factor from extracellular matrix. Cell Regul. 1:833-842.

34. Miao, H.-Q., R. Ishai-Michaeli, R. Atzmon, T. Peretz, and I. Vlodavsky. 1996. Sulfate moieties in the subendothelial extracellular matrix are involved in basic fibroblast growth factor sequestration, dimerization, and stimulation of cell proliferation. J. Biol. Chem. 271:4879-4886.

35. Strom, S.C., and G. Michalopoulos. 1982. Collagen as a substrate for cell growth and differentiation. Methods Enzymol. 82:544-555.

36. Elsdale, T., and J. Bard. 1972. Collagen substrata for studies on cell behavior. J. Cell Biol. 54:626-637.

37. Nicosia, R.F., and A. Ottinetti. 1990. Growth of microvessels in serumfree matrix culture of rat aorta. Lab. Invest. 63:115-122.

38. Roghani, M., A. Mansukhani, P. Dell'Era, P. Bellosta, C. Basilico, D.B.
Rifkin, and D. Moscatelli. 1994. Heparin increases the affinity of basic fibroblast growth factor for its receptor but is not required for binding. J. Biol. Chem. 269:3976-3984.

39. Aviezer, D., E. Levy, M. Safran, C. Svahn, E. Buddecke, A. Schmidt, G. David, I. Vlodavsky, and A. Yayon. 1994. Differential structural requirements of heparin and heparan sulfate proteoglycans that promote binding of basic fibroblast growth factor to its receptor. J. Biol. Chem. 269:114-121.

40. Vlodavsky, I., R. Bar-Shavit, G. Korner, and Z. Fuks. 1993. Extracellular matrix-bound growth factors, enzymes and plasma proteins. In Molecular and Cellular Aspects of Basement Membranes. D.H. Rohrbach and R. Timpl, editors. Academic Press Inc., Orlando, FL. 327-343.

41. Pesenti, E., F. Sola, N. Mongelli, M. Grandi, and F. Spreafico. 1992 Suramin prevents neovascularization and tumor growth through blocking of basic fibroblast growth factor activity. Br. J. Cancer. 66:367-372.

42. Mason, I.J. 1994. The ins and outs of fibroblast growth factors. Cell. 78 $547-552$.

43. Venkataraman, G., V. Sasisekharan, A.B. Herr, D.M. Ornitz, G. Waksman, C.L. Cooney, R. Langer, and R. Sasisekharan. 1996. Preferential self-association of basic fibroblast growth factor is stabilized by heparin during receptor dimerization and activation. Proc. Natl. Acad. Sci. USA. 93:845-850.

44. Mohammadi, M., I. Dikic, A. Sorokin, W.H. Burgess, M. Jaye, and J. Schlessinger. 1996. Identification of six novel autophosphorylation sites on fibroblast growth factor receptor 1 and elucidation of their importance in receptor activation and signal transduction. Mol. Cell. Biol. 16:977-989.

45. Coughlin, S.R., P.J. Barr, L.S. Cousens, L.J. Fretto, and L.T. Williams. 1988. Acidic and basic fibroblast growth factors stimulate tyrosine kinase activity in vivo. J. Biol. Chem. 263:988-993.

46. Rapraeger, A., A. Krufka, and B.R. Olwin. 1991. Requirement of heparan sulfate for bFGF-mediated fibroblast growth and myoblast differentiation Science (Wash. DC). 252:1705-1708.

47. Gitay-Goren, H., S. Soker, I. Vlodavsky, and G. Neufeld. 1992. Cell surface associated heparin-like molecules are required for the binding of vascular endothelial growth factor (VEGF) to its cell surface receptors. J. Biol. Chem. 267:6093-6098.

48. Guimond, S., M. Maccarana, B.B. Olwin, U. Lindahl, and A.C. Rapraeger. 1993. Activating and inhibitory heparin sequences for FGF-2 (basic FGF). Distinct requirements for FGF-1, FGF-2, and FGF-4. J. Biol. Chem. 268:2390623914.

49. Sartor, O., C.A. McLellan, C.E. Myers, and M.M. Borner. 1992. Suramin rapidly alters cellular tyrosine phosphorylation in prostate cancer cell lines. J. Clin. Invest. 90:2166-2174.

50. Steinfeld, R., H. van den Berghe, and G. David. 1996. Stimulation of fibroblast growth factor receptor-1 occupancy and signaling by cell surface-associated syndecans and glypican. J. Cell Biol. 133:405-416.

51. Reich-Slotky, R., D. Bonneh-Barkay, E. Shaoul, B. Bluma, C.M. Svahn, and D. Ron. 1994. Differential effect of cell-associated heparan sulfates on the binding of keratinocyte growth factor (KGF) and acidic fibroblast growth factor to the KGF receptor. J. Biol. Chem. 269:32279-32285.

52. Schmidt, A., K. Yoshida, and E. Buddecke. 1992. The antiproliferative activity of arterial heparan sulfate resides in domains enriched with 2-0-sulfated uronic acid residues. J. Biol. Chem. 267:19242-19247.

53. Cushman, M., and S. Kanamathareddy. 1990. Synthesis of the covalent hydrate of the incorrectly assumed structure of aurintricarboxylic acid (ATA). Tetrahedron. 46:1491-1498. 